\title{
THE ABSORPTION, DISTRIBUTION, AND EXCRETION OF STREPTOMYCIN IN MAN ${ }^{1}$
}

\author{
By C. W. BUGGS, MATTHEW A. PILlING, BERNICE BRONSTEIN, AND JOHN \\ WINSLOW HIRSHFELD, WITH THE TECHNICAL ASSISTANCE OF LUCILLE \\ WORZNIAK AND LOUIE J. KEY
}

\author{
(From the Department of Surgery and the Department of Bacteriology, Wayne University \\ College of Medicine, and the Division of Surgery, City of Detroit \\ Receiving Hospital, Detroit)
}

(Received for publication July 16, 1945)

Streptomycin, an antibiotic first isolated by Schatz, Bugie and Waksman (1) from the culture filtrate of Actinomyces griseus, has been shown to be effective both in vitro and in vivo against many gram-negative and gram-positive bacteria ( 1 to 7). There is also some evidence, based on the treatment of experimentally infected guinea pigs, that it may be of benefit in infections caused by Mycobacterium tuberculosis $(8,9)$. Systemic administration of streptomycin to animals has shown that they can tolerate doses that are well within the therapeutic range. These findings present the probability that streptomycin might be of value in controlling some of the human infections which do not respond to chemotherapeutic agents available at the present time. However, before streptomycin can be employed for the treatment of infections in humans, it is necessary to learn something concerning its absorption and excretion by man and about its distribution in his body. The purpose of this paper is to present the results of studies which were designed to provide this information.

\section{MATERIAL USED AND METHODS}

Streptomycin hydrochloride 2 was obtained from the manufacturer as a powder in sealed rubber-stoppered bottles which contained $1,000,000 \mathrm{E}$. coli or .S units.3 The powder was dissolved in a small amount, usually 10 ml., of sterile distilled water or physiological saline solution, and the resulting volume measured. The amount required for the desired dose was then calculated and given intramuscularly, intravenously, intrathecally, intra-

\footnotetext{
1 This work was supported by grants from the Theodore A. McGraw Fund and from Merck and Company, Inc., Rahway, N. J.

2 Provided through the courtesy of Dr. D. F. Robertson of Merck and Company, Inc.

- An E. coli or S unit of streptomycin is that quantity which when dissolved in $1 \mathrm{ml}$. of nutrient broth or agar will just suffice to inhibit the growth of a given strain of E. coli.
}

pleurally, or orally. Samples of blood, cerebrospinal fluid, ascitic fluid, and pleural fluid were obtained at suitable intervals. In some instances, pus was obtained either by aspiration or at the time of operation. All samples of peritoneal fluid obtained from patients with perforated peptic ulcer were collected when the abdomen was opened. The patients in whom urinary excretion studies were performed voided either prior to or immediately following the withdrawal of blood for assay purposes. If the patients were unable to void at the required intervals, they were catheterized. In some instances an indwelling catheter was employed.

The concentration of streptomycin in the various specimens was determined by 1 of 2 methods: (1) a twofold serial dilution method was employed for the assay of body fluids estimated to contain 1 unit or less of streptomycin per ml. and (2) the cylinder cup method recommended by Stebbins and Robinson (10) was employed for the assay of fluids estimated to contain more than 1 unit of streptomycin per $\mathrm{ml}$.

\section{The twofold serial dilution method}

This method has an inherent error of 100 per cent, but when employed for the assay of fluids with a streptomycin content of less than 1 or 2 units per ml., the error is not significant nor clinically important. The assay was carried out by 2-fold serial dilution in Kahn tubes, $0.4 \mathrm{ml}$. of the fluid under test being diluted with $0.4 \mathrm{ml}$. of nutrient broth and inoculating these dilutions with $0.3 \mathrm{ml}$. of a $1: 10^{4}$ dilution of a culture of Staphylococcus aureus that has a sensitivity to streptomycin of 0.0875 unit per 0.7 $\mathrm{ml}$. of nutrient broth. Undiluted specimens were also tested. The concentration of streptomycin in the last tube showing inhibition of the test organism is obtained by multiplying 0.0875 by 2.5 and by the dilution factor.

\section{The cup method of Stebbins and Robinson}

Some difficulty was experienced with the cup method during the initial phases of the work, and for this reason assays were not completed on a number of samples for from 2 to 3 weeks after they had been collected. However, subsequent assays, made on other samples within 2 days of collection and thereafter at weekly intervals for a month, demonstrated that no significant loss of potency occurred in urine (filtered or unfiltered), serum, pus, spinal fluid, ascitic fluid, or pleural fluid within 4 weeks.

The actual assay of the various specimens by the cup 


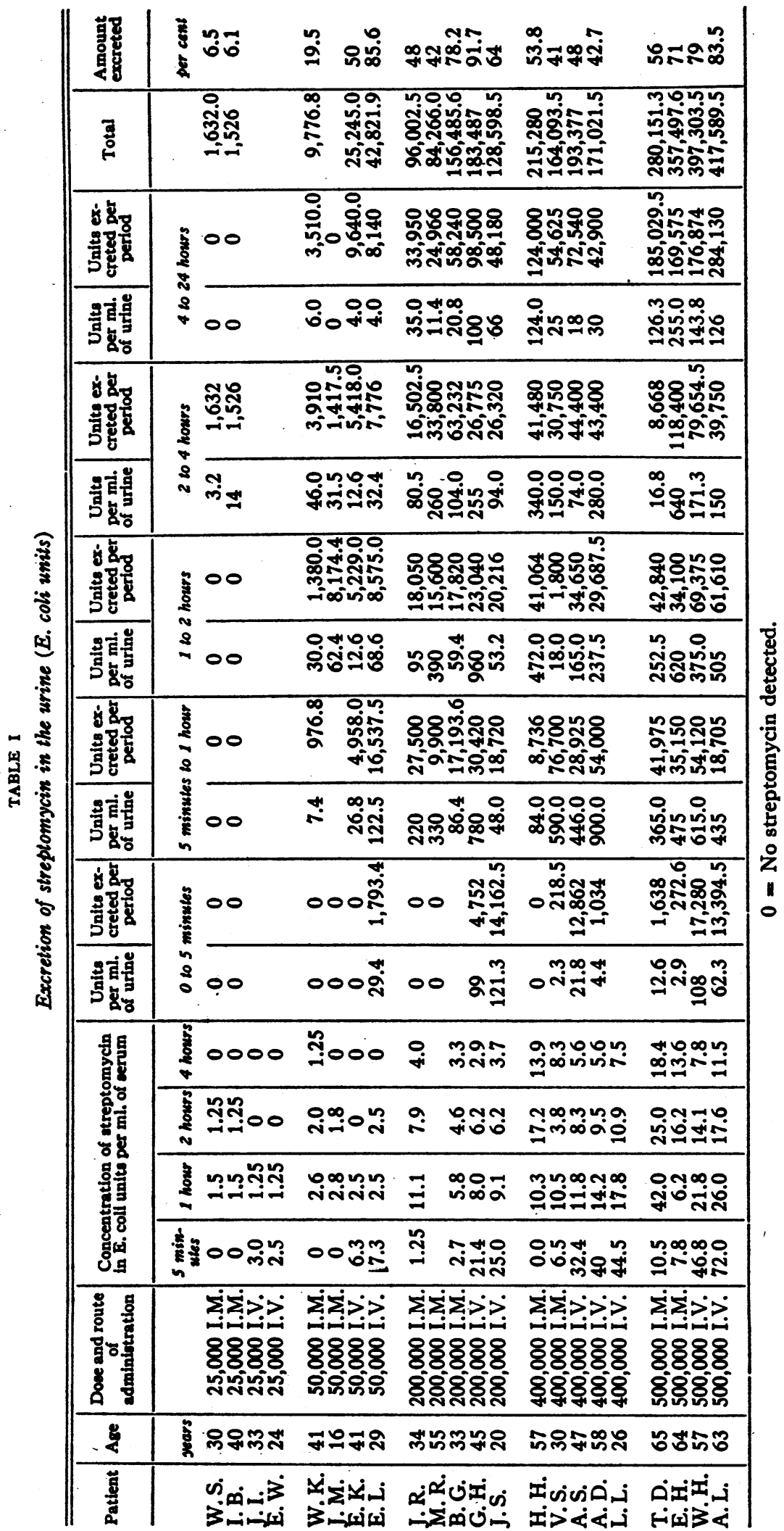


method was always preceded by a screen test of various dilutions. This was done in order to determine the dilution necessary to give a concentration between 5 and 15 units, as this range on the standard reference curve is the most accurate. Pooled serum from normal persons was used for diluting serum, and where necessary, because of their viscosity or high streptomycin content, it was also used for diluting pus, peritoneal, and chest fluid. The streptomycin concentrations reported for pus and chest fluid, and to some extent for peritoneal fluid, are somewhat lower than they should be, for in most instances the material assayed had a higher viscosity than the serum standards. Sterile distilled water was used for diluting urine and cerebrospinal fluid. After ascertaining the correct dilution, assays were done in quadruplicate, each specimen being assayed in a Petri dish containing 1 or 2 of the reference concentrations. All plates were incubated for a period of 15 to 18 hours at a temperature of $30^{\circ} \mathrm{C}$.

\section{RESULTS}

Serum concentrations of streptomycin following single intramuscular and intravenous injections

As would be expected, streptomycin was present in higher concentrations in the serum 5 minutes

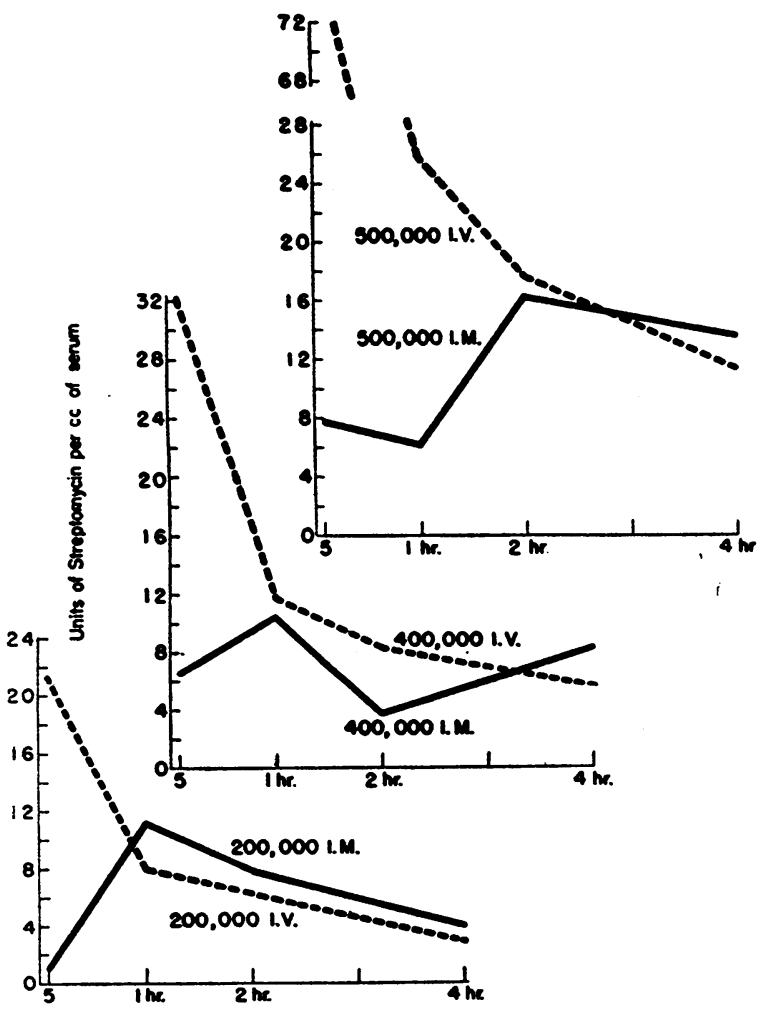

Fig. 1. Serum Concentrations of Straptomycin Following Doses of 200,000, 400,000, AND 500,000 UNITS after a single intravenous injection than after an equal quantity had been given intramuscularly (Table I and Figure 1). In general, this difference persisted throughout the first hour following the injection, but at 2 and 4 hours, the concentrations of streptomycin following a single intravenous dose did not differ markedly from the concentrations reached at these intervals following a single intramuscular injection. There is a tendency, however, for the serum concentration to remain higher for a longer period of time following the intramuscular route than when given intravenously.

In general, as the dose of streptomycin was increased the concentration of streptomycin in the serum increased and remained high longer than it did following the administration of small doses (Figures 2 and 3). The increase, however, was not proportional to the dose given. This may, in

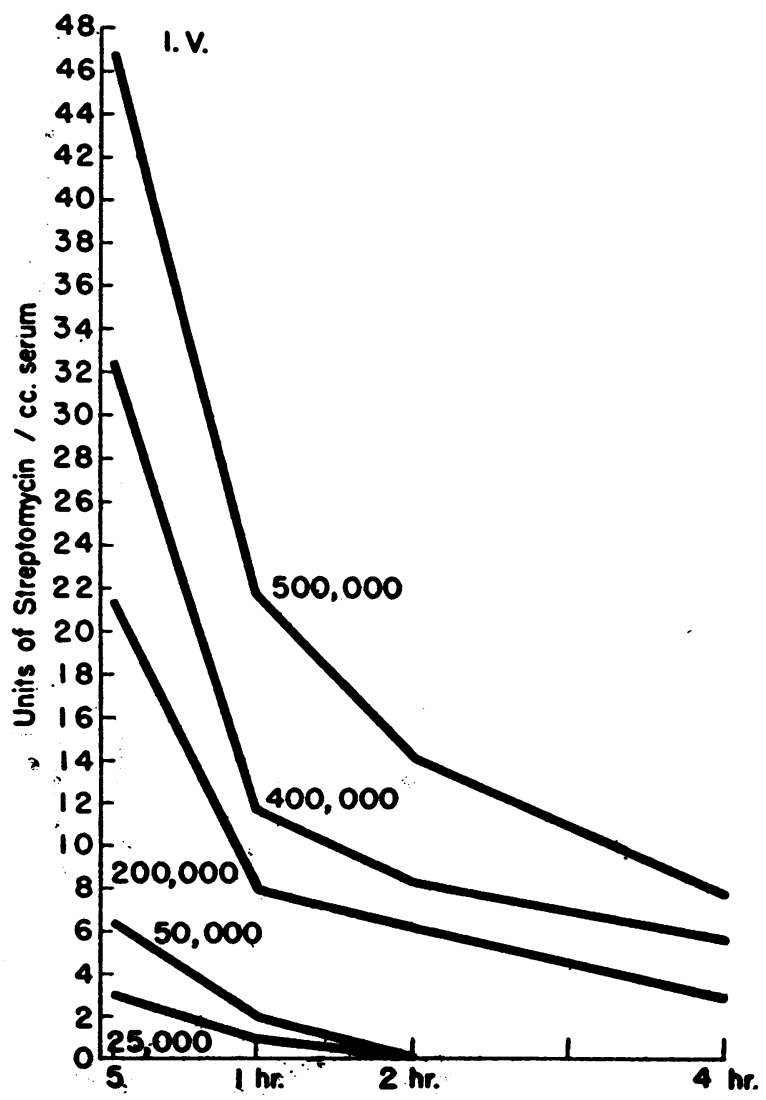

Fig. 2. Serum Concentrations of Streptomycin Obtained over a 4-Hour Period after Intravenous AdMinistration of 25,000 50,000, 200,000, 400,000 AND 500,000 UNITS 


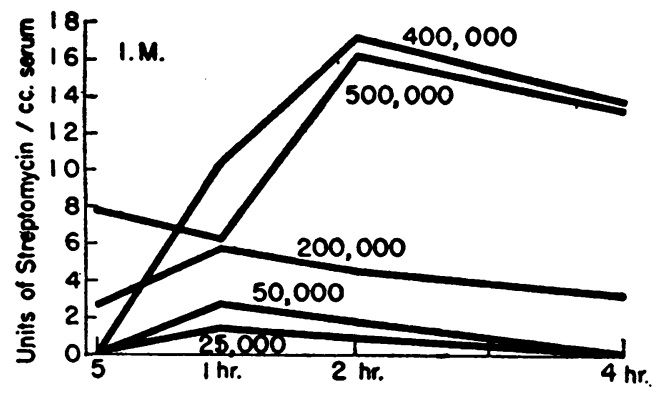

Fig. 3. Serum Concentrations of Streptomycin Obtained over a 4-Hour Period after Intramuscular AdMiNistration of $25,000,50,000,200,000,400,000$ AND 500,000 UnITS

part, be explained by individual variations. If the experiments had been conducted upon a single individual, a more precise picture of the serum concentration in relation to the dose might have been obtained. Table II shows the approximate

TABLE II

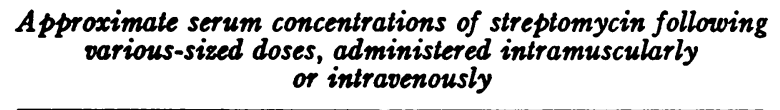

\begin{tabular}{|c|c|c|c|}
\hline $\begin{array}{l}\text { Dose of } \\
\text { atreptomycin in }\end{array}$ & \multicolumn{3}{|c|}{ E. coli units of streptomycin per ml. of serum } \\
\hline $\begin{array}{c}25,000 \\
50,000 \\
200,000 \\
400,000 \\
500,000 \\
1,000,000^{*}\end{array}$ & $\begin{array}{c}1 \text { hour afler dose } \\
1.5 \text { to } 2.5 \\
10 \\
10 \text { to } 15 \\
15 \text { to } 20 \\
25 \text { to } 50\end{array}$ & \begin{tabular}{|c|}
2 hours afler dose \\
1 to 2.5 \\
6 \\
8 \\
15 to 20 \\
25 to 45
\end{tabular} & $\begin{array}{l}4 \text { hours after dose } \\
0 \\
3 \\
6 \\
10 \text { to } 15 \\
15 \text { to } 25\end{array}$ \\
\hline
\end{tabular}

* Intramuscular data only.

serum concentrations, based upon our experience, that may be expected in adults following a single intramuscular or intravenous dose of streptomycin. Exceptions to these averages have occurred in some patients who showed abnormally low or high concentrations at a given period.

\section{Serum concentrations of streptomycin following oral administration}

No strepotmycin could be detected in the blood or urine of 2 persons 1,2 or 4 hours following a single oral dose of 500,000 units. Urine collected from 4 to 24 hours following the dose likewise contained no demonstrable streptomycin. After a single oral dose of $1,000,000$ units, streptomycin appeared in the serum of 2 persons in concentra- tions of 0.22 unit at the end of 1 hour. No streptomycin was detected at the end of 2 and 4 hours following the dose. Twenty-four-hour samples of urine contained about 0.5 unit of streptomycin per $\mathrm{ml}$. In 2 persons, after an oral dose of $2,000,000$ units, a concentration of 0.22 unit was found in the serum of one at 1,2, and 4 hours, and a concentration of 0.44 unit at 2 and 4 hours in the serum of the other. No streptomycin could be detected in the serum of this second patient at the end of 1 hour. Twenty-fourhour samples of urine from these patients contained about 1.5 units of streptomycin per $\mathrm{ml}$. Data have been presented (11) which indicate that the failure of streptomycin to appear in the serum in therapeutic amounts following oral administration is due to poor absorption rather than to destruction of streptomycin in the gastro-intestinal tract since 72 to 110 per cent of the daily dose could be detected in the feces.

\section{The excretion of streptomycin in the urine}

This study was performed on volunteers who had no apparent kidney dysfunction. Blood and urine samples were collected at the end of 5 minutes, 1 hour, 2 hours, and 4 hours, following a single intramuscular or intravenous dose of streptomycin. Urine voided during the next 20 hours was pooled and assayed as a single sample.

Reference to Table I shows that it was possible by the cup method to detect in the urine from 6.1 per cent to 91.7 per cent of the previously injected material. Generally about 50 per cent of the streptomycin appeared in the urine. These results are in agreement with those of other workers (11) who found considerable variation in the amount of streptomycin excreted in the urine.

\section{The accumulation of streptomycin in serum}

Six patients with good kidney function tolerated doses of 500,000 to $1,000,000$ units of streptomycin every 4 or 6 hours without accumulating it in their serum (Table III).

In contrast, some patients who were critically ill or who had severe renal disease exhibited increasing concentrations of streptomycin in their serum when given similar doses (Table IV). For example, H. S., a boy 4 years of age with tuberculous meningitis, had a serum level of 31.8 units 
C. W. BUGG, M. A. PILling, B. BRONSTEIN, AND J. W. HIRShFeld

TABLE III

Streptomyacin serum lovels in patients with good renal function and not critically ill. Intramuscular injections

\begin{tabular}{|c|c|c|c|c|c|c|}
\hline \multirow{2}{*}{$\begin{array}{l}\text { Patient } \\
\text { E. B. }\end{array}$} & \multirow{2}{*}{$\begin{array}{c}\text { Age } \\
\text { years } \\
14\end{array}$} & \multirow{2}{*}{$\begin{array}{l}\begin{array}{l}\text { Dose of streptomycin in } \\
\text { E. coli units }\end{array} \\
1,000,000 \text { every } 6 \text { hours } \\
\text { After } 7,000,000 \\
\text { After } 11,000,000\end{array}$} & \multicolumn{3}{|c|}{$\begin{array}{l}\text { E. coli units of streptomycin per ml. of serum } \\
\text { at the indicated intervals following injection }\end{array}$} & \multirow{2}{*}{ Diagnosis } \\
\hline & & & $\begin{array}{l}2 \text { hours } \\
36.6 \\
48.0 \\
48.4\end{array}$ & $\begin{array}{l}4 \text { hours } \\
22.5 \\
25.0 \\
42.0\end{array}$ & $\begin{array}{l}6 \text { hours } \\
17.4 \\
20.0 \\
24.4\end{array}$ & \\
\hline R. H. & 26 & $\begin{array}{l}1,000,000 \text { every } 6 \text { hours } \\
\text { After } 9,000,000 \\
\text { (Dose cut to } 500,000 \\
\text { units every } 6 \text { hours) } \\
\text { After } 14,500,000\end{array}$ & 21.4 & 31.0 & $\begin{array}{l}20.2 \\
23.6 \\
13.6\end{array}$ & $\begin{array}{l}\text { B. coli bacteremia and urinary } \\
\text { tract infection }\end{array}$ \\
\hline B. S. & 18 & $\begin{array}{l}500,000 \text { every } 6 \text { hours } \\
\text { After } 1,500,000 \\
\text { After } 7,500,000\end{array}$ & & & $\begin{array}{l}11.2 \\
12.0\end{array}$ & $\begin{array}{l}\text { Diabetes mellitus and B. coli } \\
\text { urinary tract infection }\end{array}$ \\
\hline R. D. & 15 & $\begin{array}{l}500,000 \text { every } 6 \text { hours } \\
\text { After } 1,500,000 \\
\text { After } 7,500,000\end{array}$ & & & $\begin{array}{l}15.2 \\
16.8\end{array}$ & Urinary tract infection \\
\hline M. D. & 21 & $\begin{array}{l}500,000 \text { every } 6 \text { hours } \\
\text { After } 1,500,000 \\
\text { After } 7,500,000\end{array}$ & & & $\begin{array}{l}15.2 \\
13.8\end{array}$ & B. coli urinary tract infection \\
\hline L. $\mathbf{N}$. & 43 & $\begin{array}{l}500,000 \text { every } 6 \text { hours } \\
\text { After } 4,000,000 \\
\text { After } 7,500,000\end{array}$ & & & $\begin{array}{l}14.2 \\
14.2\end{array}$ & $\begin{array}{l}\text { Diabetes mellitus and urinary } \\
\text { tract infection }\end{array}$ \\
\hline
\end{tabular}

6 hours after a single intramuscular injection of 750,000 units. Since the boy was critically ill, therapy was continued by giving 750,000 units intramuscularly every 6 hours. He received a total of 2,250,000 units. Six hours after the last dose, the serum concentration of streptomycin was 171 units per ml. The accumulation may have been due to the size of the dose rather than to inability of the patient to excrete or destroy the streptomycin. However, similar retention of the drug has been observed in adults who were seriously ill. These findings, plus the fact that some individuals seem to excrete or destroy streptomycin very rapidly make it imperative that the concentration of streptomycin in serum be determined for each patient receiving the drug in order to regulate the dose intelligently and safely.

The appearance of streptomycin in cerebrospinal fluid following intramuscular and intravenous injections

Cerebrospinal fluid from 5 patients with no meningeal involvement was assayed following a single injection of 500,000 units of streptomycin. Four of the patients received the antibiotic intravenously; 1 received it intramuscularly. Lumbar puncture was performed from $11 / 2$ to 3 hours after streptomycin was administered. In no instance could streptomycin be detected in the cerebrospinal fluid. In a sixth patient, a boy with tuberculous meningitis, streptomycin was detected in the cerebrospinal fluid in a concentration of $\mathbf{1 3 . 2}$ units 3 hours after the intramuscular administration of 750,000 units. At this time, the serum concentration was 95.2 units. Six hours after receiving a total of $2,250,000$ units of streptomycin at the rate of 750,000 units every 6 hours, this patient had a serum concentration of 171 units per ml., and a concentration of 41.6 units per $\mathrm{ml}$. was found in his cerebrospinal fluid. Although in normal individuals streptomycin does not penetrate the blood-brain barrier to appear in the cerebrospinal fluid following a single systemic injection of 500,000 units, the single case of tuberculous meningitis reported in this paper demonstrates that streptomycin may penetrate into the cerebrospinal fluid after systemic injection if the meninges are inflamed.

\section{Streptomycin administered by intrathecal injection}

Five volunteers were each given a single dose of streptomycin intrathecally. Two of the patients 
received 10,000 units, 2 received 15,000 units, and 1 received 20,000 intrathecally (Table V). Spinal fluid was withdrawn after 24 hours at which time a cell count was made and the fluid assayed by means of the cup method for its streptomycin content. The 24-hour assay values of spinal fluid seem to indicate that from 15,000 to 20,000 units of streptomycin administered intrathecally is sufficient to give therapeutic concentrations over a 20 or 24 -hour period. All but 1 of the patients listed in the table (V) complained of symptoms, such as pain in the cervical region and headache. These patients also exhibited an increase in the number of cells in the spinal fluid. Since all of these patients had received streptomycin from the same lot, streptomycin from another lot was administered to 2 additional patients. One patient received 15,000 units and one received 20,000 units. Neither patient developed any of the symptoms experienced by the previous groups of patients, but both of them showed an increase in the spinal fluid cell count. Whether these irritative phenomena are due to a property of streptomycin or to an impurity in the preparations employed is not known. Until this point has been settled, it would seem wiser to be cautious in the intrathecal injection of streptomycin.
The appearance of streptomycin in peritoneal fluid following systemic administration

A single intravenous dose of 500,000 units of streptomycin was given to 4 patients with perforated peptic ulcer shortly after their admission to the hospital. Samples of peritoneal fluid were obtained at operation, and blood samples were drawn at approximately the same time. Streptomycin was detected in therapeutic amounts in the peritoneal fluid of all the patients (Table VI). These data indicate that systemic administration of the drug should be efficacious shortly after the onset of peritonitis. Whether streptomycin penetrates into peritoneal fluid or pus in peritonitis of longer duration is unknown.

The appearance of streptomycin in ascitic fluid following systemic administration

Single doses of streptomycin in 500,000-unit amounts were administered to 5 patients with ascites due to cirrhosis of the liver, or cardiac failure. Four received the drug intramuscularly and one received it intravenously. Streptomycin was detected in the ascitic fluid in appreciable amounts, especially in view of the large amount of fluid removed from one of the patients. The concentrations ranged from 1.75 to 12.5 units per ml.

TABLE IV

Streptomycin serum levels in patients critically ill. Intramuscular injections

\begin{tabular}{|c|c|c|c|c|c|c|c|c|}
\hline \multirow{2}{*}{$\begin{array}{l}\text { Patient } \\
\text { M. C. }\end{array}$} & \multirow{2}{*}{$\begin{array}{c}\text { Age } \\
\text { years } \\
37\end{array}$} & \multirow{2}{*}{$\begin{array}{l}\text { Dose of streptomycin in E. coli units } \\
\\
1,000,000 \text { every } 4 \text { hours } \\
\text { After } 4,000,000 \\
\text { After } 10,000,000\end{array}$} & \multicolumn{5}{|c|}{$\begin{array}{l}\text { E. coli units of streptomycin per ml. } \\
\text { of serum at the indicated intervals } \\
\text { following injection }\end{array}$} & \multirow[b]{2}{*}{ Recurrent multiple abscesses } \\
\hline & & & 1 hour & 2 hours & 3 hours & $\begin{array}{r}4 \text { hours } \\
\\
34.2 \\
40.5\end{array}$ & \begin{tabular}{|r|}
6 hours \\
\\
11.8 \\
27.0
\end{tabular} & \\
\hline H. S. & 4 & $\begin{array}{l}750,000 \text { every } 6 \text { hours } \\
\text { After } 2,250,000\end{array}$ & & 106.0 & 95.2 & 55.3 & $\begin{array}{r}31.8 \\
171.0\end{array}$ & Tuberculous meningitis \\
\hline A. D. & 50 & $\begin{array}{l}2,000,000 \text { by cont. I.V. drip } \\
\text { over a } 24 \text {-hour period for a } \\
\text { total of } 5,000,000 \text { units. } \\
\text { Changed after } 5,000,000 \text { to } \\
1,000,000 \text { every } 6 \text { hours I.M. } \\
\text { After } 6,000,000 \\
\text { After } 7,000,000 \\
\text { After } 10,000,000\end{array}$ & 77.6 & 71.2 & & $\begin{array}{l}80.8 \\
95.2\end{array}$ & 65.6 & $\begin{array}{l}\text { Generalized peritonitis. B. } \\
\text { coli bacteremia }\end{array}$ \\
\hline M. W. & 39 & $\begin{array}{l}1,000,000 \text { every } 6 \text { hours } \\
\text { After } 22,500,000\end{array}$ & 173.0 & & & 152.0 & 173.0 & Abdominal abscess \\
\hline D. $\mathrm{H}$. & 37 & $\begin{array}{l}1,000,000 \text { every } 4 \text { hours } \\
\text { After } 9,000,000\end{array}$ & & & & $>160$ & & $\begin{array}{l}\text { Intestinal obstruction. Pel- } \\
\text { vic abscess }\end{array}$ \\
\hline M. B. & 59 & $\begin{array}{l}500,000 \text { every } 6 \text { hours } \\
\text { After } 11,500,000\end{array}$ & & & & & $>160.0$ & $\begin{array}{l}\text { Diabetic. Gangrene right } \\
\text { leg with urinary infection }\end{array}$ \\
\hline
\end{tabular}


TABLE $\mathbf{V}$

Results of intrathecal administration of streptomycin

\begin{tabular}{|c|c|c|c|c|c|c|}
\hline Patient & Age & Dose & $\begin{array}{l}\text { CSF after } \\
24 \text { hrs. }\end{array}$ & $\begin{array}{c}\text { Cell count } \\
\text { before } \\
\text { administra- } \\
\text { tion of } \\
\text { streptomycin }\end{array}$ & $\begin{array}{l}\text { Cell count } 24 \text { hours after } \\
\text { administration of } \\
\text { streptomycin }\end{array}$ & Symptoms \\
\hline F. $\mathbf{M}$. & $\begin{array}{c}\text { years } \\
37\end{array}$ & 20,000 & $\begin{array}{l}\text { unils per ml. } \\
20.2\end{array}$ & $\begin{array}{c}20 \\
100 \text { per cent } \\
\text { Lymph. }\end{array}$ & $\begin{array}{l}292-80 \text { per cent polymorpho- } \\
\text { nuclear leukocytes. } 20 \text { per } \\
\text { cent lymphocytes }\end{array}$ & $\begin{array}{l}\text { General malaise for } 24 \text { hours. } \\
\text { Edema and erythema of face } \\
\text { for } 12 \text { hours }\end{array}$ \\
\hline A. $\mathrm{H}$. & 49 & 15,000 & 13.5 & 4 & $\begin{array}{l}1500-90 \text { per cent polymorpho- } \\
\text { nuclear leukocytes }\end{array}$ & $\begin{array}{l}\text { Headache. Pain in the cervical } \\
\text { region }\end{array}$ \\
\hline F. K. & 59 & 15,000 & 25.4 & 3 & $\begin{array}{l}243-89 \text { per cent polymorpho- } \\
\text { nuclear leukocytes }\end{array}$ & $\begin{array}{l}\text { General malaise. Occipital } \\
\text { headache }\end{array}$ \\
\hline R. S. & 34 & 10,000 & 0.875 & & & No complaints \\
\hline Q. W. & 51 & 10,000 & 3.7 & 3 & $\begin{array}{l}180-80 \text { per cent polymorpho- } \\
\text { nuclear leukocytes }\end{array}$ & $\begin{array}{l}\text { Frontal headache. Pain in the } \\
\text { cervical region }\end{array}$ \\
\hline
\end{tabular}

2 to 4 hours following administration of the drug (Table VII).

The appearance of streptomycin in pleural fluid following systemic administration

Streptomycin, like penicillin, was found to appear only slowly in 3 thoracic empyemas following systemic administration. About 1 unit per $\mathrm{ml}$. of pus could usually be detected in $31 / 2$ hours after a single intramuscular dose of 500,000 or $1,000,000$ units. This value is probably low, due to the viscosity of the material assayed. In 2 cases of tuberculosis in which fluid was aspirated from the

TABLE VI

The appearance of streptomycin in peritoneal fluid of patients with perforated peptic ulcer

\begin{tabular}{|c|c|c|c|c|c|}
\hline \multirow{2}{*}{$\begin{array}{l}\text { Pa- } \\
\text { tient }\end{array}$} & \multirow{2}{*}{ Age } & \multirow{2}{*}{$\begin{array}{l}\text { Dose of } \\
\text { streppomycin } \\
\text { in } E_{\text {. coli }} \\
\text { units }\end{array}$} & \multirow{2}{*}{$\begin{array}{c}\text { Time } \\
\text { after dose }\end{array}$} & \multicolumn{2}{|c|}{$\begin{array}{l}\text { Concentration of } \\
\text { streptomycin in } \\
\text { E. coli units }\end{array}$} \\
\hline & & & & In serum & $\begin{array}{l}\text { In } \\
\text { peritoneal } \\
\text { fluid }\end{array}$ \\
\hline G. H. & $\begin{array}{l}\text { years } \\
45\end{array}$ & 500,000 I.V. & $\begin{array}{l}\text { hours } \\
1 \\
1 \frac{1}{2}\end{array}$ & 21.5 & 22.0 \\
\hline w. S. & 45 & 500,000 I.V. & 2 & 15.0 & 14.9 \\
\hline Z. B. & 39 & 500,000 I.V. & $1 \frac{1}{4}$ & 25.5 & 16.2 \\
\hline E. $\mathbf{M}$. & 50 & 500,000 I.V. & $1 \frac{1}{1 \frac{1}{2}}$ & 19.5 & 17.8 \\
\hline
\end{tabular}

chest, streptomycin was detected in amounts of 2.4 and 3.0 units per $\mathrm{ml}$. of fluid after the administration of $1,000,000$ and 500,000 units, respectively.

\section{Toxic manifestations of streptomycin}

A number of toxic symptoms were observed in the patients who received streptomycin. Among these were flushing of the skin, headache, and a sense of fullness in the head shortly after injection of the drug. Two patients who were given 500,000 units intravenously over a 1 - to 2 -minute period complained of a bad taste in the mouth, dizziness, and respiratory difficulty. Both patients lost consciousness for a period of 3 to 5 minutes, during which time the pulse was imperceptible.

TABLE VII

The appearance of streptomycin in ascitic fluid following systemic injection

\begin{tabular}{|c|c|c|c|c|c|c|}
\hline \multirow{2}{*}{$\underset{\text { tient }}{\mathrm{Pa}-}$} & \multirow{2}{*}{ Age } & \multirow{2}{*}{$\begin{array}{c}\text { Dose of } \\
\text { streptomycin } \\
\text { in E. coli units }\end{array}$} & \multirow{2}{*}{$\begin{array}{l}\text { Time } \\
\text { after } \\
\text { dose }\end{array}$} & \multicolumn{2}{|c|}{$\begin{array}{l}\text { E. coli units of } \\
\text { streptomycin }\end{array}$} & \multirow{2}{*}{ Diagnosis } \\
\hline & & & & $\begin{array}{c}\text { In } \\
\text { se- } \\
\text { rum }\end{array}$ & $\begin{array}{c}\text { In } \\
\text { ascitic } \\
\text { fluid }\end{array}$ & \\
\hline J. D. & $\begin{array}{l}\text { years } \\
53\end{array}$ & 500,000 I.M. & $\begin{array}{c}\text { hours } \\
3 !\end{array}$ & & 2.25 & Cirrhosis of liver \\
\hline J.w. & 60 & 500.000 I.M. & 4 & 12.8 & 4.8 & $\begin{array}{l}\text { Cardiac decom- } \\
\text { pensation }\end{array}$ \\
\hline F.H. & 54 & 500,000 I.M. & 4 & 10.2 & 3.2 & Cirrhosis of liver \\
\hline L. C. & 60 & $1,000,000$ I.M. & $2\}$ & 28.0 & 12.5 & $\begin{array}{l}\text { Cardiac decom- } \\
\text { peneation }\end{array}$ \\
\hline L. B. & 46 & 400,000 I.M. & 2 & 3.5 & 1.75 & $\begin{array}{l}\text { Cardiac decom- } \\
\text { pensation }\end{array}$ \\
\hline
\end{tabular}


Recovery was rapid in both instances, and no abnormal sequellae were noted.

Forty-five patients received the drug therapeutically for from 1 to 18 days. The total dose administered to these patients varied from $1,500,000$ to $30,500,000$ units. Of this group, 13 exhibited toxic symptoms other than those described above. Three developed fever which subsided when streptomycin was discontinued. A rash occurred in 2 patients. Nine patients complained of generalized aching, a feeling of weakness, and pain in the joints. One patient who had a very high concentration of streptomycin in her serum (173 units per $\mathrm{ml}$. 6 hours after receiving 22,500,000 units intramuscularly, at the rate of $1,000,000$ units every 6 hours) developed painful swelling of her wrists. All of these toxic symptoms disappeared promptly when the drug was discontinued. They seemed to occur more frequently with certain lots of streptomycin than with others. Whether they are caused by a property inherent in streptomycin or whether they are due to impurities which can be eliminated by improvement in the process of manufacture is as yet unknown. It can be said, however, that many patients tolerated large doses of streptomycin quite well and in them it was possible to maintain serum concentrations within a therapeutic range.

\section{SUMMARY}

The absorption and excretion of streptomycin following systemic and oral administration was studied in 22 persons. Doses of 25,000 to 500,000 units were given intramuscularly or intravenously, and doses of 500,000 to $2,000,000$ units were given orally. Generally, after intramuscular or intravenous injection, about 50 per cent of the dose was excreted in the urine within 24 hours. Streptomycin was not absorbed from the gastro-intestinal tract following a single dose of 500,000 units, but traces appeared in both blood serum and urine after doses of one and two million units.

Serum concentrations of streptomycin following the systemic administration of 25,000 and 50,000 units were less than 3 units per cu. $\mathrm{cm}$. at the end of 1 hour. No streptomycin was detected in the serum of 7 out of 8 patients at the end of 4 hours following injection of these amounts. Doses of 500,000 units, given either intramuscularly or in- travenously every 6 hours, seemed to maintain a serum level adequate to combat bacteria whose growth is inhibited by concentrations of 5 to 7.5 units of streptomycin per ml. of culture medium. The serum concentrations during the first few minutes after the injection of a given dose of streptomycin intravenously were much higher than those attained following a similar dose administered intramuscularly. In general, however, by the end of 1 hour, the serum concentrations were approximately equal whether the drug had been given intravenously or intramuscularly. This condition persisted until the end of the fourth hour when the concentrations following the intramuscular injection were found to be slightly higher than those following the intravenous injection.

No streptomycin was found at the end of three hours in the spinal fluid of 5 normal persons after a single dose of 500,000 units given intramuscularly or intravenously. When administered intrathecally in doses ranging from 10,000 to 20,000 units, streptomycin was detected in the spinal fluid in concentrations of 0.875 to 25.4 units at the end of 24 hours. Some toxic manifestations, pain in the cervical region, headache, and an increase in spinal fluid cell count, followed the injection of 10,000 to 20,000 units of streptomycin intrathecally.

Streptomycin was found to penetrate into the peritoneal cavity in substantial amounts in early cases of peritonitis resulting from ruptured peptic ulcer following a single intravenous injection of 500,000 units.

Streptomycin in amounts ranging from 1.75 to 12.5 units per $\mathrm{ml}$. was detected in ascitic fluid following systemic injection. Like penicillin, streptomycin injected intramuscularly did not penetrate into empyema cavities in therapeutic amounts although traces could be detected in the pus.

A number of patients complained of flushing of the skin, a sense of fullness in the head, or headache shortly after the intramuscular or intravenous injection of a large dose of streptomycin. Two patients who were given 500,000 units intravenously over a 1- to 2-minute period complained of a bad taste in the mouth, dizziness, and respiratory difficulty. Both patients lost consciousness for 3 
to 5 minutes during which time the pulse was imperceptible. Recovery in both instances was rapid and no abnormal sequellae occurred.

Thirteen of 45 patients who received streptomycin therapeutically for 1 to 18 days complained of generalized muscular aching, a feeling of weakness, or pain in the joints. Three of these patients developed drug fever, and a rash occurred in 2. All of these symptoms cleared when the drug was discontinued.

\section{BIBLIOGRAPHY}

1. Schatz, A., Bugie, E., and Waksman, S. A., Streptomycin, a substance exhibiting antibiotic activity against gram-positive and gram-negative bacteria. Proc. Soc. Exper. Biol. \& Med., 1944, 55, 66.

2. Heilman, F. R., Streptomycin in the treatment of experimental infections with micro-organisms of the Friedlander group (Klebsiella). Proc. Staff Meeting of Mayo Clin., 1945, 20, 33.

3. Jones, D., Metzger, H. J., Schatz, A., and Waksman, S. A., Control of gram-negative bacteria in experimental animals by streptomycin. Science, 1944, $100,103$.
4. Robinson, H. J., Smith, D. G., and Graessle, O. E., Chemotherapeutic properties of streptomycin. Proc. Soc. Exper. Biol. \& Med., 1944, 57, 226.

5. Heilman, F. R., Streptomycin in the treatment of experimental tularemia. Proc. Staff Meeting of Mayo Clin., 1944, 19, 553.

6. Waksman, S. A., and Reilly, H. C., Bactericidal action of antibiotic substances. J. Infect. Dis., 1944, $75,150$.

7. Waksman, S. A., Bugie, E., and Schatz, A., Isolation of antibiotic substances from soil microorganisms, with special reference to streptothricin and streptomycin. Proc. Staff Meeting of Mayo Clin., 1944, $19,537$.

8. Feldman, W. H., and Hinshaw, H. C., Effects of streptomycin on experimental tuberculosis in guinea pigs: A preliminary report. Proc. Staff Meeting of Mayo Clin., 1944, 19, 593.

9. Schatz, A., and Waksman, S. A., Effect of streptomycin and other antibiotic agents upon Mycobacterium tuberculosis and related organisms. Proc. Soc. Exper. Biol. \& Med., 1944, 57, 244.

10. Stebbins, R. B., and Robinson, H. J., A method for determination of streptomycin in body fluids. Proc. Soc. Exper. Biol. \& Med., 1945, 59, 255.

11. Reimann, H. A., Elias, W. F., and Price, A. H., Streptomycin for typhoid. J.A.M.A., 1945, 128, 175. 